\title{
PROFITABILITY OF INVESTMENT IN THE DEVELOPMENT OF THE SAILING INFRASTRUCTURE OF SMALL POLISH SEAPORTS
}

\author{
Piotr NOWACZYK \\ Zachodniopomorski Uniwersytet Technologiczny, Szczecin; Piotr.nowaczyk@ zut.edu.pl, \\ ORCID: 0000-0001-8625-1959
}

\begin{abstract}
The process of developing sailing facilities in small seaports of the Polish coast has not been completed. Simultaneously, there is an ongoing debate on the purposefulness of investing in the capital-intensive sailing infrastructure. Therefore, the main aim of this article is to conduct an analysis of profitability of sailing investments. The article also attempts to show the importance of sailing tourism in a broader context of the local economy. The article uses methods of literature review, in-depth interview, as well as comparative and statistical analysis. In order to calculate the break-even point for sailing investments, the FNPV indicator was used. Research results have shown unprofitability of sailing investments for port operators, although most sailing facilities did generate income. The diversified profitability of sailing facilities resulted from hydrotechnical conditions, administrative and location restrictions, as well as the scope of services provided. Sailing tourism positively impacts local economy. The sailors' spendings - through a multiplier effect - stimulate the development of port municipalities and alleviate unprofitability of sailing investments. While deciding upon the expansion of sailing facilities, a full spectrum of impact of sailing tourism on local economy should be taken into consideration, including benefits which are difficult to quantify, and not just the financial situation of port operators. In order to increase the impact of sailing tourism on local economy, one should strive to extend the stay of sailors in ports by expanding the range of services offered. The sailing product could be enriched through creating a sailing cluster out of local tourism enterprises.
\end{abstract}

Keywords: sailing infrastructure, sailing tourism, small seaports, local economy, financial analysis.

\section{Introduction}

In the recent several years, a significant change has occurred in the business profiles of small seaports on the Polish coast. The hitherto dominant function of servicing fishery began to regress, due to the decreasing fish resources. The decreasing importance of fisheries raises a discussion on the possibilities of bridging the gap in the business structure of seaports. 
One of the alternatives is sailing tourism, for which coastal areas are particularly predisposed. The growing wealth of the society and the expansion of the nautical infrastructure in the recent years have increased tourists' interest in sailing facilities (harbors and marinas). The popularity of nautical tourism is favored by the change in contemporary tourist trends, including the growing demand for various forms of qualified and specialized tourism (Meyer, 2005; Promocja, 2013). The literature on the subject often emphasizes the importance of sailing tourism as an important element of regional and local development (Kaup, 2010; Durydiwka, 2013; Guzik, Ostrowska, 2013). All these circumstances should indicate sailing tourism as a promising area of activity for small seaports. The above thesis is also confirmed by domestic and foreign experts on the subject (Heflich, 2011; Jugović et al., 2012; Łapko, 2015). However, in the literature on the subject, different opinions can also be found (Szwichtenberg, 2001). The competitiveness of the Polish sailing sector is limited by natural and climatic conditions. The argumentation includes examples of Scandinavian countries, where the formation of the coastline does not require high expenditure on construction and subsequent maintenance of sailing infrastructure. On the other hand, in the Mediterranean basin, climatic conditions extend the sailing season, which affects the financial situation of port operators. Finally, not all coastal countries invest in the development of sailing facilities, such as Germany, for which the main reason is the demographic crisis and over-investing. Also some representatives of the domestic port sector question the legitimacy of further expansion of capital-intensive sailing infrastructure, indicating low profitability of projects in the situation of limited access to investment funds.

The ambiguity of attitudes and opinions raises the question of the purposefulness of investing in the further development of sailing facilities. Hence, the main purpose of the article is to analyze the profitability of sailing investments from the point of view of the investment project beneficiaries. The article also attempts to show the importance of sailing tourism in a broader context of the local economy.

The issues discussed in the article are important and current in the context of the ongoing discussion on the directions of development of small seaports, which the recently amended Act on seaports and harbors refers to. The process of developing nautical infrastructure has not been completed. Some ports are considering the expansion of current sailing facilities or constructing new ones. The national literature on the subject lacks comprehensive studies dealing with the issue of profitability of sailing investments, which results, among others, from the recently completed expansion of sailing facilities (Butowski et al., 2015). However, as they have been operating for several years now, it allows for a preliminary assessment of investment activities. Foreign literature also rarely raises the issue of economic aspects of the development of sailing infrastructure, and if it does, it mainly concerns large yacht ports (Report, 2015; EC, 2016; Gerke et al.; 2018). Furthermore, as has already been mentioned, the conditions of development of sea sailing tourism show significant diversity on an international scale. 


\section{Materials \& Methods}

The article uses secondary and primary sources of information. The analysis of secondary sources included books, publications, legal acts, statistical yearbooks, and reports from the daily press. Research was conducted in the form of in-depth interviews with representatives of small seaports. The respondents were CEOs/managers of port management entities - port operators, directors of sailing associations and owners of tourist enterprises. The territorial scope of research includes eight small seaports, representing each section of the Polish Baltic coast: Dziwnów, Kołobrzeg, Darłowo, Ustka, Łeba, Władysławowo, Jastarnia, and Hel. The vast majority of domestic sailing traffic concentrates in these ports. The research was conducted in the years 2018-2019.

The statistical material collected during the research includes data on sailing traffic and the profitability of sailing facilities obtained from port operators. Detailed statistical data was obtained only from two ports, i.e. Darłowo and Kołobrzeg. In other ports, the method of collecting statistical data made it impossible to isolate individual categories of financial flows related to the service of sailing - especially in terms of costs. In the case of those ports, information on profitability was obtained on the basis of in-depth interviews. Therefore, the data presented in the article has an estimated value. Cost calculation is also different for commercial law companies (Kołobrzeg, Darłowo, Ustka, Łeba, Władysławowo, Hel) and for budgetary units (Dziwnów, Jastarnia) ${ }^{1}$. Similarly, data on sailing traffic broken down into domestic and foreign vessels from the ports in Dziwnów and Hel is estimated.

Statistical data was used to determine the break-even point of the sailing investment using the Financial Net Present Value (FNPV) ratio. The financial analysis is conducted from the point of view of the investment beneficiary, in the case of small seaports - port operators, and is used to determine the cash flows directly related to the functioning of the investment (Drobniak, 2008) $)^{2}$. It takes into account the size of investment outlays and the profitability of investments, i.e. profitability at the operational level. ${ }^{3}$ Since sailing facilities were financed from EU funds, FNPV was calculated in two variants: with and without subsidies. In the case of the seaport in Ustka, FNPV was only calculated in the second variant, since the yacht marina was not co-financed from EU funds. The calculation of the FNPV for the yacht marina in Łeba, co-financed from PHARE funds and commissioned in 1998, thus in another planning period of the EU budget, required the adjustment of the investment value by a discount rate, which was adopted at the level of $6 \%$, which corresponded to the recommendations at the time.

\footnotetext{
${ }^{1}$ The necessity to pay corporate income tax and to calculate depreciation puts commercial law companies in a less favorable position.

${ }^{2}$ Pursuant to the guidelines on financing infrastructure investments from EU funds for sailing facilities, a fifteenyear reference period was adopted, for which cash flow calculations were made.

${ }^{3}$ In accordance with the recommendations of the European Commission for projects financed from structural funds and the European Cohesion Fund of the European Union budget for 2007-2013, a discount rate of 5.0\% was adopted (Guidelines, 2013).
} 
For Władysławowo, financial analysis was not conducted, due to the inaccessibility of statistical data.

When estimating the coefficient of utilization of the sailing potential (occupancy of sailing facilities), the number of yachts calling at ports, the time a vessel spent at the port, the number of free places for host yachts and the six-month period of the sailing season were taken into account. In the case of parking spaces reserved for residents, full occupancy was assumed.

Estimating the annual expenses of sailors required distinguishing between domestic and foreign units, due to the varying amounts of expenses for both categories of tourists. The average stopping time in the port and the average number of sailors were taken into account. A detailed justification for the adopted methodology is included in the previously published article (Nowaczyk, 2018). The estimated values do not include residents' expenses, due to the lack of accurate data. In ports, where they constitute the dominant group of sailors, such as in Jastarnia and Kołobrzeg, failure to include residents may significantly lower the estimated values. Two categories of residents, i.e. those residing in and outside the municipality, should also be taken into account. The expenses of the former lead mainly to redistribution of local income, affecting the financial situation of port operators, while slightly stimulating local development. On the other hand, "external" residents have a greater significance for the local economy.

\section{Results}

The profitability of investment projects depends on the amount of financial surplus necessary to cover investment outlays. ${ }^{4}$ Table 1 presents data on the amount of investment outlays for the development of sailing infrastructure in the examined ports in the years $1998^{5}$ and in 2011-2018. The value of implemented investment projects amounted to PLN 64.4 million, of which PLN 30.7 million came from EU funds (47.7\% of the investment value), and the remaining PLN 33.7 million from municipal funds and port managing entities $52.3 \%$ of the investment value). The value of the investment varied and ranged from PLN 0.4 million in Ustka to PLN 40.3 million in Leba, which was mainly due to the scale of the investment (size of sailing facilities with associated infrastructure), construction of sailing facilities (bridges made of plastic, wood or concrete) and in the field of investment (modernization or construction). In ports, where the existing port quays did not require modernization or deepening of the port basins, and the accompanying infrastructure for sailors was limited, investment outlays were the lowest, as was the case in Darłowo and in Ustka - additionally a small scale of investment was combined with the innovative construction of the yacht marina.

\footnotetext{
${ }^{4}$ Taking into account the market discount rate - author's note.

${ }^{5}$ In 1998, the yacht marina in Łeba was commissioned. In the remaining ports, the process of development of sailing infrastructure began in 2011.
} 
However, in ports where sailing facilities were built from scratch, i.e. with the construction of quays, access roads, the need to guarantee the appropriate depth of port basins, with an extensive accompanying infrastructure and a significant number of parking spaces, investment outlays were the highest - the example of Łeba, to a lesser extent Kołobrzeg and Dziwnów.

Table 1.

The amount of investment outlays (PLN million) for the development of sailing infrastructure in the researched small seaports in 2011-2018

\begin{tabular}{|l|l|c|l|}
\hline \multirow{2}{*}{ Name of port } & \multicolumn{1}{|c|}{ name of investment } & $\begin{array}{c}\text { value of } \\
\text { investment }\end{array}$ & \multicolumn{1}{c|}{ sources of funding } \\
\cline { 2 - 4 } Dziwnów & $\begin{array}{l}\text { Construction of a harbor } \\
\text { and a yacht marina }\end{array}$ & 8.3 & $\begin{array}{l}\text { municipal funds 5.0 } \\
\text { EU funds 3.3 }\end{array}$ \\
\hline Kołobrzeg & modernization of the yacht marina & 10.2 & $\begin{array}{l}\text { municipal and ZPM (Port Authority) } \\
\text { funds 4.2 } \\
\text { EU funds } 6.0\end{array}$ \\
\hline Darłowo & construction of a yacht marina & 1.2 & $\begin{array}{l}\text { municipal funds 0.5 } \\
\text { EU funds 0.7 }\end{array}$ \\
\hline Ustka & $\begin{array}{l}\text { construction of floating bridges } \\
\text { for yachts }\end{array}$ & 0.4 & $\begin{array}{l}\text { municipal funds } 0.3 \\
\text { ZPM funds 0.1 }\end{array}$ \\
\hline Leba & $\begin{array}{l}\text { construction of a yacht marina } \\
\text { with accompanying infrastructure }\end{array}$ & 40.3 & $\begin{array}{l}\text { national public funds 22.6 } \\
\text { EU funds 17.7 }\end{array}$ \\
\hline Władysławowo & n.d. & n.d. & n.d. \\
\hline Jastarnia & $\begin{array}{l}\text { reconstruction of the yacht marina } \\
\text { Stage I and Stage II }\end{array}$ & 2.3 & $\begin{array}{l}\text { municipal funds } 0.5 \\
\text { EU funds 1.8 }\end{array}$ \\
\hline Hel & $\begin{array}{l}\text { modernization and reconstruction } \\
\text { of the yacht marina }\end{array}$ & 1.7 & $\begin{array}{l}\text { ZPM funds 0.5 } \\
\text { EU funds 1.2 }\end{array}$ \\
\hline Total & $\begin{array}{l}\text { Investment process } \\
\text { national public funds 33.7 } \\
\text { EU funds 30.7 }\end{array}$ \\
\hline
\end{tabular}

Explanation: Łeba - the table includes a yacht marina in Łeba which was commissioned in 1998; n.d. - no data; ZPM - Zarząd Portu Morskiego (Port Authority).

Source: own study on the basis of conducted research.

Table 2 presents numerical data on the profitability of sailing facilities in Darłowo and Kołobrzeg. Table 3 - due to the lack of reliable statistical data - presents opinions of the respondents on the profitability of sailing facilities in the remaining studied seaports. The presented tables show that four sailing facilities generate income, two facilities balance and bring loss.

Table 2.

Profitability of sailing facilities (PLN thousand) in the ports of Kotobrzeg and Dartowo in the years 2013-2018

\begin{tabular}{|c|c|c|c|c|c|c|c|c|c|}
\hline \multirow{2}{*}{$\begin{array}{c}\text { Name } \\
\text { of port }\end{array}$} & \multirow{2}{*}{$\begin{array}{l}\text { Financial } \\
\text { categories }\end{array}$} & \multicolumn{6}{|c|}{ Years } & \multirow{2}{*}{ Total } & \multirow{2}{*}{$\begin{array}{c}\text { Annual } \\
\text { average }\end{array}$} \\
\hline & & 2013 & 2014 & 2015 & 2016 & 2017 & 2018 & & \\
\hline \multirow{3}{*}{ Darłowo } & revenues & 105.7 & 159.7 & 174.3 & 151.6 & 100.3 & 192.0 & 883.6 & 147.3 \\
\hline & costs & 67.0 & 79.2 & 81.6 & 110.7 & 138.7 & 152.4 & 518.9 & 86.5 \\
\hline & income & 38.7 & 80.5 & 92.7 & 40.9 & -38.4 & 39.6 & 254.0 & 42.3 \\
\hline \multirow{3}{*}{ Kołobrzeg* } & revenues & n.d. & n.d. & n.d. & 709.8 & 753.5 & 871.3 & $2,334.6$ & 778.2 \\
\hline & costs & n.d. & n.d. & n.d. & 708.6 & 752.2 & 869.8 & $2,330.6$ & 776.9 \\
\hline & income & n.d. & n.d. & n.d. & 1.2 & 1.3 & 1.5 & 4.0 & 1.3 \\
\hline
\end{tabular}

Explanation: Kołobrzeg $^{*}$ - due to the problem with obtaining reliable statistical data, the analysis of financial situation of the yacht marina in Kołobrzeg was limited to the years 2016-2018.

Source: own study on the basis of conducted research. 
Table 3.

Profitability of sailing facilities in the remaining studied seaports, based on the opinions of respondents

\begin{tabular}{|c|c|}
\hline Name of port & Profitability of harbors/marinas \\
\hline Dziwnów & balanced \\
\hline Ustka & loss $^{1}$ \\
\hline Leba & loss $^{1}$ \\
\hline Władysławowo & profit $^{2}$ \\
\hline Jastarnia & profit $^{2}$ \\
\hline Hel & balanced \\
\hline
\end{tabular}

Explanation: $\operatorname{loss}^{1}$ - in the respondents' opinion, the estimated average annual loss on sailing activities in Ustka and in Leba may amount to PLN 20,000 and PLN 280,000-300,000, respectively; profit ${ }^{2}$ - according to respondents' opinions, the estimated average annual profitability of marinas in Jastarnia and Władysławowo may amount to several thousand PLN.

Source: own study on the basis of conducted research.

Data from Tables 2 and 3 were used to calculate the break-even points for sailing investments on the basis of the FNPV - in the variant with EU subsidies, and the variant without. The values of the ratios are presented in Table 4, which shows that the return on investment outlays in the variant with the subsidy will take place with the average annual income generated from sailing facilities in the range from nearly PLN 70,000 for ports in Darłowo, Jastarnia and Hel, PLN 500,000-600,000 for ports in Kołobrzeg and Dziwnów, up to over PLN 3,000,000 for Łeba. None of the studied ports, neither on the basis of detailed data (Tab. 2), nor on the basis of estimates based on experts' opinions (Tab. 3), achieved an average annual income guaranteeing a return on investment outlays. In the case of the variant without subsidies, the investment outlays are reimbursed at a much higher level, i.e. from nearly PLN 60,000 for Ustka, more than PLN 1,000,000 for Kołobrzeg and Dziwnów, to nearly PLN 6,000,000 in the case of Łeba. The least profitable investments - in both variants - turned out to be the marina in Leba, followed by Kołobrzeg and the sailing facilities in Dziwnów (the alternation of places results from different levels of subsidies). The smallest losses in the variant with a subsidy were generated by the marina in Darłowo, and then in Jastarnia and Hel. In the variant without a subsidy, apart from the three ports already mentioned, also the marina in Ustka brought about losses.

Table 4.

Break-even threshold (PLN thousand) for sailing investments calculated on the basis of the FNPV ratio in the variant with a subsidy and without a subsidy

\begin{tabular}{|c|c|c|c|c|}
\hline \multirow{2}{*}{ Name of port } & \multicolumn{4}{|c|}{ Breakeven threshold } \\
\cline { 2 - 5 } & FNPV - with & $\begin{array}{c}\text { average annual deficit, taking } \\
\text { into account subsidies }\end{array}$ & $\begin{array}{c}\text { FNPV - } \\
\text { without } \\
\text { a subsidy }\end{array}$ & $\begin{array}{c}\text { average annual } \\
\text { deficit without } \\
\text { subsidy }\end{array}$ \\
\hline Dziwnów & 693.3 & $693.3^{*}$ & $1,150.9$ & $1,150.9^{*}$ \\
\hline Kołobrzeg & 582.4 & 580.48 & $1,414.4$ & $1,412.5$ \\
\hline Darłowo & 69.3 & 0.4 & 166.4 & 97.5 \\
\hline Ustka & does not apply & does not apply & 55.5 & $91.4^{*}$ \\
\hline Leba & $3,133.0$ & $3,621.7^{*}$ & $5,589.0$ & $6,077.7^{*}$ \\
\hline Władysławowo & n.d. & n.d. & n.d. & n.d. \\
\hline Jastarnia & 69.3 & $<69.3$ & 235.9 & $<318.9$ \\
\hline Hel & 69.3 & $69.3^{*}$ & $235.7^{*}$ \\
\hline
\end{tabular}


Explanation: an asterisk indicates an estimate, “<” means the value minus the estimated profitability of the marina in Jastarnia of several thousand PLN on average annually; n.d.- no data.

Source: own study on the basis of conducted research.

\section{Discussion}

The financial analysis of port operators showed that sailing facilities are not able to generate income to cover investment expenses. It is caused by the already mentioned high investment outlays, but also by considerable costs of maintaining sailing facilities - especially the deepening of port basins. There are also factors limiting the revenues of port operators. These include weather conditions with rainy tourist seasons ${ }^{6}$ - especially when combined with port facilities which are not attractive for tourists. Another issue is the military training ground located on the sea between Darłowo and Ustka, which impedes free sailing. A factor mentioned by the port operator in Darłowo is limiting promotional campaigns among foreign sailors. Another factor is the limited scope and low quality of provided sailing services (which will be discussed further in the article). Thus, a question arises, whether to further invest in the development of sailing tourism, knowing that the majority of respondents declared the will to expand the existing sailing infrastructure (Tab.5.). Only the representatives of the ports in Darłowo and Jastarnia did not see the need to increase the sailing potential. However, in the Jastarnia port, in 2019, the second stage of expansion of the marina was completed, which was equipped with additional berths. The main motivation, prompting respondents to invest, was the growing interest of tourists in sailing facilities. Although, based on the value of the sailing potential utilization factor, it can be stated, that the demand for mooring spaces exceeded the capacity of sailing facilities only in the ports of Kołobrzeg and Ustka. It was in those ports that, especially during the peak of the tourist season, sailors often moored their vessels at the quays which also fulfilled other port functions. The main reason for making investments impossible were restrictions on access to financial resources (smaller amount of EU funds for the development of water tourism for 2014-2020). Own funds of the entities managing the ports usually did not allow for the implementation of capital-intensive sailing investments, with a value ranging from a few to several million PLN.

\footnotetext{
${ }^{6}$ Such situation occurred in the 2016-2017 season, which was reflected in the lower volume of sailing traffic.
} 
Table 5.

Utilization of sailing potential (\%) and plans to expand sailing facilities in the opinion of respondents

\begin{tabular}{|c|c|c|c|c|c|}
\hline Name of port & $\begin{array}{c}\text { Number of } \\
\text { mooring } \\
\text { spaces }\end{array}$ & $\begin{array}{c}\text { Number of } \\
\text { yacht calls }\end{array}$ & $\begin{array}{c}\text { Demand for } \\
\text { mooring spaces }\end{array}$ & $\begin{array}{c}\text { Utilization of } \\
\text { sailing potential } \\
\text { (\%) }\end{array}$ & $\begin{array}{c}\text { Expansion of } \\
\text { sailing facilities }\end{array}$ \\
\hline Dziwnów & 90 & 947 & insufficient & 66.8 & planned \\
\hline Kołobrzeg & 64 & 1402 & insufficient & 100.0 & planned \\
\hline Darłowo & 67 & 540 & sufficient & 88.1 & not planned \\
\hline Ustka & 30 & 443 & insufficient & 100.0 & planned \\
\hline Łeba & 120 & 990 & sufficient & 51.1 & planned \\
\hline Władysławowo & 12 & 979 & insufficient & 90.6 & planned \\
\hline Jastarnia & 137 & 681 & sufficient & 81.0 & not planned \\
\hline Hel & 60 & 3343 & insufficient & 46.4 & planned \\
\hline
\end{tabular}

Source: own study on the basis of conducted research.

It seems that, without the support of local authorities, further development of sailing tourism will be significantly impeded. But will port municipalities be willing to finance unprofitable investments? The impact of sailing tourism on local development is not limited merely to the port operators. Among the beneficiaries are tourism enterprises, local community and local government units. The development of nautical tourism also generates benefits that are difficult or impossible to quantify; these include: promotions of port municipalities as centers developing water sports and seaside recreation, increasing interest in sailing among young people and adults, as well as integration of the local community. Difficulties in determining accurately the impact of sailing on the development of the local economy also result from the nature of tourism, which is a complex phenomenon and creates numerous links in the tourism service chain (Milewski, 2007; Meyer, 2008). In this article, the impact of nautical tourism on the local economy is limited to estimating the expenses of sailors. In 2018, sailors' expenses, depending on the port, could range from several hundred thousand PLN for smaller sailing facilities, such as Ustka and Władysławowo, up to several million for the port of Kołobrzeg (Tab. 6.). Most of these funds remain in the local economy as tax receipts for city budgets, employee wages, and profits of tourist enterprises. It should be noted, that the sailors' expenses are many times higher than the value of the FNPV indicator - without subsidies, determining the profitability threshold for investments (Tab. 4). An exception here is the port in Dziwnów, for which both values are similar, and the port in Łeba, in case of which the expenses of sailors are much lower than the value of the FNPV, even in the variant with a subsidy. However, the real impact of nautical tourism on the local economy can be much greater, as sailors' expenses do not take into account the multiplier effects - money circulation in the economy. The literature on the subject shows that the value of the multiplier in economically developed regions dominated by the local small and medium-sized enterprises sector employing the local population may range from 2 to 3 . This means, that each monetary unit put into circulation (the original expenses of sailors) generates an additional one or two monetary units in further business transactions. The conducted research shows, that most service providers in port municipalities belong to the sector of small and medium-sized enterprises of local capital. 
Thus, it should be expected that the local economy will benefit more than the initial spending of sailors would suggest.

Table 6.

Estimated value of sailors' expenses (PLN thousand) in the surveyed small seaports in 2018

\begin{tabular}{|c|c|c|c|c|c|c|}
\hline \multirow{2}{*}{ Name of port } & \multicolumn{2}{|c|}{ Number of yacht calls } & \multirow{2}{*}{$\begin{array}{c}\text { Person per } \\
\text { night per } \\
\text { yacht }\end{array}$} & \multicolumn{2}{|c|}{ Sailors' expenses } & \multirow{2}{*}{$\begin{array}{c}\text { Expenses in } \\
\text { total }\end{array}$} \\
\hline & domestic & foreign & & domestic* & foreign* & \\
\hline Dziwnów & $316^{*}$ & $631^{*}$ & 6 & 210.5 & 951.4 & $1,161.9$ \\
\hline Kołobrzeg & 439 & 1,402 & 7.5 & 365.5 & $2,642.4$ & $3,007.9$ \\
\hline Darłowo & 181 & 359 & 12 & 241.1 & $1,082.6$ & $1,323.7$ \\
\hline Ustka & 195 & 248 & 3 & 64.9 & 186.0 & 250.9 \\
\hline Łeba & 396 & 594 & 2 & 87.9 & 298.5 & 386.4 \\
\hline Władysławowo & 609 & 370 & 3 & 202.8 & 278.9 & 481.7 \\
\hline Jastarnia & 630 & 51 & 21 & $1,468.5$ & 269.1 & $1,737.6$ \\
\hline Hel & $2,005^{*}$ & $1,338^{*}$ & 4 & 890.2 & $2,343.2$ & $3,233.4$ \\
\hline
\end{tabular}

Explanation: domestic*, foreign* - average expenses of tourists per one day in Poland in the first half of 2018, which were PLN 111.00 for domestic tourists, and USD 72 / PLN 251.3 for foreign tourists (with the exchange rate $(\mathrm{USD} 1=\mathrm{PLN} 3,49)$.

Source: own study on the basis of NBP, Exchange rates, https://www.nbp.pl/home. aspx?f=/kursy/ arch_a.html, Charakterystyka przyjazdów do Polski w I pótroczu 2018 roku oraz Charakterystyka krajowych i zagranicznych podróży mieszkańców Polski w I pótroczu 2018 roku, Ministerstwo Sportu i Turystyki, Warszawa.

The estimates presented in Tab.6 undoubtedly speak for investing in the development of sailing tourism. However, sailors' expenses are a manifestation of indirect influence of tourism on local development. How to increase or reduce the shortfall of sailing investments? It is impossible to extend the sailing season, eliminate hydrotechnical and administrative barriers, and the impact of adverse weather conditions. Investment outlays can be reduced by building sailing facilities in a less capital-consuming way, using the already existing quays. Nonetheless, this is not always possible. In the case of floating bridges, better performance is provided by the concrete structure, which is more expensive. It should be remembered, that the surveyed seaports are exposed to negative impact of sea waters. It became an almost common tendency to increase the number of parking spaces for "permanent" sailors, the so-called residents, and to offer the possibility of wintering yachts. In some ports, e.g. in Kołobrzeg and Jastarnia, the vast majority of revenues are generated by residents. This is undoubtedly the right direction for the development of sailing tourism, eliminating the phenomenon of seasonality. However, it is not sufficient. The research conducted by the author showed, that ports offer a limited range of sailing services. Kołobrzeg is the only port that provides comprehensive services. This includes not only strictly sailing services, such as servicing, chartering, winterizing, or bunkering of vessels, but also catering and accommodation services. For instance, revenues from additional services rendered by the company managing the yacht marina in Łeba cover the deficit of the marina. In Western Europe, some sailing marinas go 
"a step further", offering services not related directly to sailing activity (Lapko, 2015) ${ }^{7}$. Also in this case, the only port offering such services is Łeba, although, at the same time, the port lacks a comprehensive infrastructure to service sailing traffic, hence the place to expand the yacht marina. In most of the surveyed ports, however, providing tourist services is not profitable due to the low volume of sailing traffic. Acquisition of service providers would require the expansion of sailing facilities in order to increase the number of mooring spaces for yachts. However, there is a problem here. Why invest in sailing facilities if the sailing potential of some of them is not fully utilized already (Tab. 5). In the author's opinion, the development of the sailing sector can be justified, provided it is organized in the form of a cluster ${ }^{8}$. Sailing clusters successfully function in Western Europe, bringing their members measurable benefits (Gerke et al., 2018). However, the success of cluster initiatives depends on fulfilling a few basic conditions: beneficial location, heterogeneity of the tourist product, the presence of numerous tourism enterprises willing to cooperate, tourism demand and connections between cluster members and public authorities, research and development units, as well as business environment institutions. If the cluster reaches the so-called "critical mass", that is, a size which enables it to develop on its own, it will undoubtedly increase the attractiveness of investing in sailing facilities. However, development of clusters is a lengthy process ${ }^{9}$, which requires perseverance from its initiators, especially public authorities. In this context, Związek Małych Portów Morskich [Association of Small Seaports], founded in 2016, should be positively assessed, as it may become the nucleus of a future sailing cluster.

\section{Conclusions}

The article attempts to answer the question about the purposefulness of further expansion of the sailing infrastructure in small seaports. Research results proved sailing investments to be deficient for port operators. Some facilities did not generate income at all. However, this does not prejudge the failure to invest in sailing infrastructure. Firstly, infrastructural investments are usually characterized by negative profitability on the financial level, with sailing constructions being no exception. Secondly, if not sailing, then what activity should be

\footnotetext{
${ }^{7}$ For example, the yacht marina in Kröslin, Germany, in addition to the typical sailing infrastructure with 500 berths for yachts, is equipped with extensive complementary facilities, including: three restaurants, a spa, houses on the water, a post office, a shipyard, 500 wintering places, a hairdressing salon, a shopping mall, land-based apartments, a massage salon, a gas station, a playground, a barbecue spot, a gift shop, a conference room, a bank.

${ }^{8}$ In 2013, a sailing cluster called "Polski Klaster Żeglarski" [Polish Sailing Cluster] was created in the West Pomerania Voivodeship. It is, however, a faulty organization, which departs in its construction from theoretical premises and international experience. Thus, it does not bring the intended benefits to its members.

${ }^{9}$ For example, according to M. E. Porter, it takes 10 or more years for a cluster to reach its mature form. The long period of waiting for the results is one of the main reasons for ineffectiveness of actions undertaken by public authorities.
} 
developed in small seaports in the face of the regression of Baltic fishery? Passenger transport? Cargo handling? These are certainly promising areas of port activity, but an infrastructure, which is perhaps even more capital-intensive, is necessary for their implementation. Some ports are not suited for transshipment at all, so in those cases the infrastructural base would have to be created from scratch. Moving away from typical port functions could be considered, focusing, for example, on the construction of recently popular apartment buildings in coastal towns. Apart from the sensitivity of the development sector to the economic situation which has recently been particularly favorable to investors by contributing to oversupply what benefits can the local economy expect from luxury buildings, if the buyers are usually external entities? What part of the revenue will be introduced into the local economic circulation? What should be done in the event of a downturn and falling prices, and consequently a reduction in property tax revenues in the city budgets?

The conducted research shows, that the development of sailing tourism benefits local economy. New money is introduced into its circulation, which, through tourism enterprises, stimulates other sectors of the economy. Therefore, ports should strive to extend the stay of sailors by expanding the range of services offered. Ultimately, creation of a sailing cluster can be considered, which will require the cooperation of tourist enterprises with public authorities, scientific and research units, as well as market environment institutions. The animators of the cluster initiative can be port management entities associated in the Association of Small Seaports.

Hydro-technical restrictions, administrative and location issues, as well as the range of services that can be offered to sailors should all be taken into consideration while making decisions on the expansion of sailing infrastructure. The benefits of developing sailing tourism for the local economy should be taken into account. In ports with significant utilization of the sailing potential, decisions on the expansion of the sailing infrastructure should certainly be considered, while in others it should be sought to make greater use of it. Each time, potential issues with funding the investment should be kept in mind.

\section{References}

1. Butowski, L., Łopaciński, K., Neifeld, M., Owsiak, J., Radkowska, B., Sewerniak, J., and Wechman, K. (2015). Studium wykonalności projektu „Zachodniopomorski Szlak Żeglarski-sieć portów turystycznych Pomorza Zachodniego". Szczecin: Zachodniopomorska Regionalna Organizacja Turystyczna.

2. Charakterystyka krajowych i zagranicznych podróży mieszkańców Polski w I pótroczu 2018 roku. Retrieved from https://www.msit.gov.pl/pl/turystyka/badania-rynku-turystycz/ 
statystyka-komunikaty-i/8055, Charakterystyka-krajowych-i-zagranicznych-podrozymieszkancow-Polski-w-I-polrocz.html, 24.08.2019.

3. Charakterystyka przyjazdów do Polski w I pótroczu 2018 roku. Retrieved from https://www.msit.gov.p1/pl/turystyka/badania-rynku-turystycz/statystyka-komunikatyi/8054,Charakterystyka-przyjazdow-do-Polski-w-I-polroczu-2018-roku.html, 24.08.2019.

4. Drobniak, A. (2008). Podstawy oceny efektywności projektów publicznych. Katowice: Wydawnictwo Akademii Ekonomicznej.

5. European Commission (2016). Assessment of the Impact of Business Development Improvements around Nautical Tourism. Retrieved from https://www.europeanboating industry.eu/images/Documents/For_publications/Business-development-around-nauticaltourism.pdf, 24.08.2019.

6. Gerke, A., and Pria, Y.D. (2018). Cluster Concept: Lessons for the Sport Sector? Toward a Two-Step Model of Sport Cluster Development Based on Socioeconomic Proximity. Journal of Sport Management, 32(3), 211-226, doi: https://doi.org/10.1123/jsm. 2016-0338.

7. Guzik, H., Ostrowska, B. (2013). Ekonomiczne aspekty gospodarowania przestrzenią turystyczną. Zeszyty Naukowe Uniwersytet Ekonomiczny w Krakowie, 913, 63. Retrieved from https://zeszyty-naukowe.uek.krakow.pl/article/view/759/584, 24.08.2019.

8. Heflich, W. (2011). Twarzą do wody. Magazyn sportów wodnych „Żagle”, 8, 5. Retrieved from https://zagle.se.pl/zeglarstwo/082011-twarza-do-wody-felieton-waldemara-heflichaaa-Fv4L-Wuk9-jXLs.html, 24.08.2019.

9. Kaup, M. (2010). Rola i znaczenie jachtingu w rozwoju polskiej turystyki wodnej. Folia pomeranae universitatis technologiae stetinensis. Oeconomica, 284(61), 17. Retrieved from http://foliaoe.zut.edu.pl/pdf/files/magazines/2/28/269.pdf, 24.08.2019.

10. Łapko, A. (2015). Turystyka żeglarska. Warszawa: Bel Studio.

11. Luković, T. (2012). Nautical Tourism and its Functions in the Economic Development in Europe. In: M. Kasimoglu (Ed.), Visions for Global Tourism Industry - Creating and Sustaining Competitive Strategies (pp. 416-418). Rijeka: In Tech.

12. Meyer, B. (2005). Aktywność turystyczna i rekreacyjna. In: B. Meyer (ed.), Obstuga uczestników turystyki i rekreacji, 19. Warszawa: Difin.

13. Meyer, B. (2008). Gospodarka turystyczna i przemysł turystyczny. In: A. Panasiuk (ed.), Gospodarka turystyczna (pp. 16-20). Warszawa: PWN.

14. Milewski, D. (2007). Mnożnik turystyczny. In: A. Panasiuk (ed.), Ekonomika turystyki (pp. 54-59). Warszawa: PWN.

15. NBP. Kursy walut. Retrieved from https://www.nbp.pl/home.aspx?f=/kursy/arch_a.html, 24.08.2019.

16. Nowaczyk, P. (2018). Direct and indirect impact of nautical tourism on the development of local economy in West Pomerania on the example of Darłowo municipality. Acta Scientiarum Polonorum. Seria: Oeconomia, 17(2), 79-88. doi: 10.22630/ASPE.2018. 17.2.23. 
17. Porter, M.E. (2001). Porter o konkurencji. Warszawa: PWE.

18. Promocja (2013). Promocja obszaru LSROR Pojezierze Suwalsko-Augustowskie stan aktualny, wyzwania $i$ kierunki działań. Retrieved from http://lgr-pojezierze.eu/wpcontent/uploads/2014/04/Promocja-obszaru-LSROR.pdf, 24.08.2019.

19. Report (2015). Study on the competitiveness of the recreational boating sector. Retrieved from https://ec.europa.eu/growth/tools-databases/vto/content/study-competitiveness-recre ational-boating-sector, 24.08.2019.

20. Szwichtenberg, A. (2001). Turystyka szansą rozwoju społeczno-gospodarczego regionów nadmorskich. In: A. Szwichtenberg (ed.), Współczesne problemy funkcjonowania turystyki w polskiej nadmorskiej strefie turystycznej (pp. 107-122). Gdańsk: Civitas Christiana.

21. Wytyczne Ministra Rozwoju Regionalnego w zakresie wybranych zagadnień zwiazanych $z$ przygotowaniem projektów inwestycyjnych, $w$ tym projektów generujących dochód. Retrieved from https://www.funduszeeuropejskie.gov.pl/strony/o-funduszach/dokumenty/ wytyczne-ministra-infrastruktury-i-rozwoju-w-zakresie-zagadnien-zwiazanych-zprzygotowaniem-projektow-inwestycyjnych-w-tym-projektow-generujacych-dochod-iprojektow-hybrydowych-na-lata-2014-2020-1/, 24.08.2019. 